\title{
PEMAHAMAN EDUKASI TRANSPORTASI SEBAGAI UPAYA PENDIDIKAN KARAKTER SISWA DI SMP INSAN CENDEKIA TURI
}

\author{
Anik Widiastuti \\ Agus Sudarsono \\ Raras Gistha Rosardi \\ Jurusan Pendidikan IPS, Fakultas Ilmu Sosial, UNY \\ email: anikwidiastuti@uny.ac.id, No. Hp 085213323505
}

\begin{abstract}
Abstrak
Penelitian dengan judul Pemahaman Edukasi Transportasi sebagai Upaya Pendidikan Karakter Siswa SMP Insan Cendekia Turi bertujuan untuk mengetahui tingkat pengetahuan dan keterampilan bagi para siswa SMP Insan Cendekia Turi tentang tata tertib serta etika berlalu lintas. Pengetahuan dan keterampilan tentang tata tertib dan etika berlalu lintas yang diperoleh melalui kegiatan penelitian ini diharapkan dapat meningkatkan karakter siswa-siswi sebagai upaya mengurangi jumlah pelanggaran lalu lintas sehingga dapat meminimalisir terjadinya kecelakaan lalu lintas. Penelitian ini dilatarbelakangi karena SMP Insan Cendekia Turi memiliki lokasi yang dekat dengan jalan raya akan tetapi tidak terlalu banyak angkutan umum yang dapat diakses siswa dari rumahnya sehingga banyak siswa yang harus membawa kendaraan bermotor ke sekolah. Penelitian ini menggunakan metode ceramah, demonstrasi, dan simulasi. Sampel dalam penelitian ini sebanyak 60 siswa. Hasil evaluasi menunjukkan bahwa hasil tes penguasaan materi, serta hasil angket kepuasan pelaksanaan didominasi oleh siswa yang termasuk dalam kategori baik, sehingga dapat dikatakan cukup berhasil. Hal di atas menunjukkan bahwa penguasaan siswa terhadap materi transportasi dapat dikatakan baik karena didominasi oleh siswa yang memiliki skor hasil tes dalam kategori tinggi sebanyak 27 siswa dan yang memperoleh skor hasil tes dengan kategori rendah hanyak 10 siswa saja. Hal di atas menunjukkan tingkat kepuasan siswa terhadap kegiatan penelitian dapat dikatakan baik karena didominasi oleh siswa yang memberi skor angket dalam kategori tinggi sebanyak 38 siswa dan yang memberi skor hasil angket dengan kategori rendah hanyak 5 siswa saja.
\end{abstract}

Kata Kunci: edukasi, transprotasi, karakter 
Abstract

The study untitled "Understanding Education as an Effort Transportation Character Education Junior high school students Insan Scholar Turi" aims to determine the level of knowledge and skills for junior high school students Insan Scholar Turi on order and traffic ethics. Knowledge and skills about the rules and ethics of traffic obtained through this research activity is expected to improve the character of the students in an effort to reduce the number of traffic violations in order to minimize the occurrence of traffic accidents. This research is motivated because the school Insan Scholar Turi has a location close to the highway but not too much of public transport accessible to students of his house so many students have to bring the motor vehicle to school. Whereas Insan Scholar Turi junior high school students have never gained the socialization of the regulation in road traffic. This research activity using lectures, demonstrations, and simulations. The sample in this study were 60 students. The results showed that the test result mastery of the material, as well as the implementation of the satisfaction questionnaire results are dominated by students included in either category, so it can be quite successful. The above shows that the students' mastery of the material transport can be said to be good because it is dominated by students who score in the test results of the high category and as many as 27 students who obtained scores lower test results by category only complains 10 students only. The above shows the level of student satisfaction on research activities can be good because it is dominated by students who gave a score of questionnaire in high category as many as 38 students and gave a score of the questionnaire results with lower category only complains 5 students only.

Keywords: education, transportation, character

\section{Pendahuluan}

Transportasi dilihat dalam konteks pendidikan adalah usaha sadar untuk menumbuhkan kesadaran tertib bertransportasi, sehingga peserta didik mampu mengendalikan atau mengurangi timbulnya kecelakaan lalu lintas. Edukasi transportasimerupakan serangkaian usaha secara terprogram dan tersistem untuk melahirkan generasi yang memiliki etika dan budaya tertib 
Anik Widiastuti, Agus Sudarsono, Raras Gistha Rosardi

bertransportasi. Edukasi transportasi menfokuskan pada penanaman pengetahuan tentang etika bertransportasi (transfer of knowledge) dan menanamkan nilai-nilai (tranform of values) etika dan budaya tertib bertransportasi dan membangun perilaku pada generasi muda.

Siswa SMP memiliki pemahaman minim mengenai etika bertransportasi, akan tetapi belum banyak program yang dilakukan oleh pemerintah, sekolah, maupun orang tua siswa untuk memberikan edukasi transportasi. Data WHO tahun 2011 menyebutkan, sebanyak 67 persen korban kecelakaan lalu lintas berada pada usia produktif, yakni 22 - 50 tahun. Terdapat sekitar 400.000 korban di bawah usia 25 tahun yang meninggal di jalan raya, dengan rata-rata angka kematian 1.000 anak-anak dan remaja setiap harinya. Bahkan, kecelakaan lalu lintas menjadi penyebab utama kematian anak-anak di dunia, dengan rentang usia 10-24 tahun.

(http:/ /www.bin.go.id/awas/detil/197/4/21/03/2013/kecelakaanlalu-lintas-menjadi-pembunuh-terbesar-etiga\#sthash.kqEfY91G.dpuf).

Akan tetapi kenyataannya, banyak dijumpai di masyarakat yang membiarkan anak-anak dibawah umur (dibawah 17 tahun, belum memiliki KTP dan SIM) usia anak SMP s/d SMU sudah diijinkan bersekolah dengan mengendarai kendaraan bemotor, tanpa memikirkan keselamatan anaknya, yang jelas usia anak itu belum tahu akan bahaya dan cara-cara yang baik dan sopan dalam berkendara dan cenderung didorong emosi muda yang membara, makin ngebut makin hebat. Ini bisa dilihat pada jam-jam sekolah setiap pagi dan siang saat mereka pergi dan pulang sekolah dengan seragam sekolah tapi sudah naik motor. World Health Organization 
(WHO) Indonesia menyatakan bahwa, 90 persen penyebab terjadinya kecelakaan di Indonesia disebabkan oleh faktor lalai, yaitu mengantuk, sakit, tidak sabar, dan tidak menghargai pengguna jalan lain saat berkendara. Ketidaksiapan psikologis juga merupakan bagian dari kelalaian berkendara. Faktor-faktor tersebut harusnya menjadi perhatian kita semua untuk dapat dihindari sebagai upaya meminimalisir terjadinya kecelakaan lalu lintas. Sumber lain menyebutkan faktor penyebab terjadinya kecelakaan lalu lintas selain faktor-faktor di atas yang dapat dilihat pada diagram lingkaran di bawah ini.

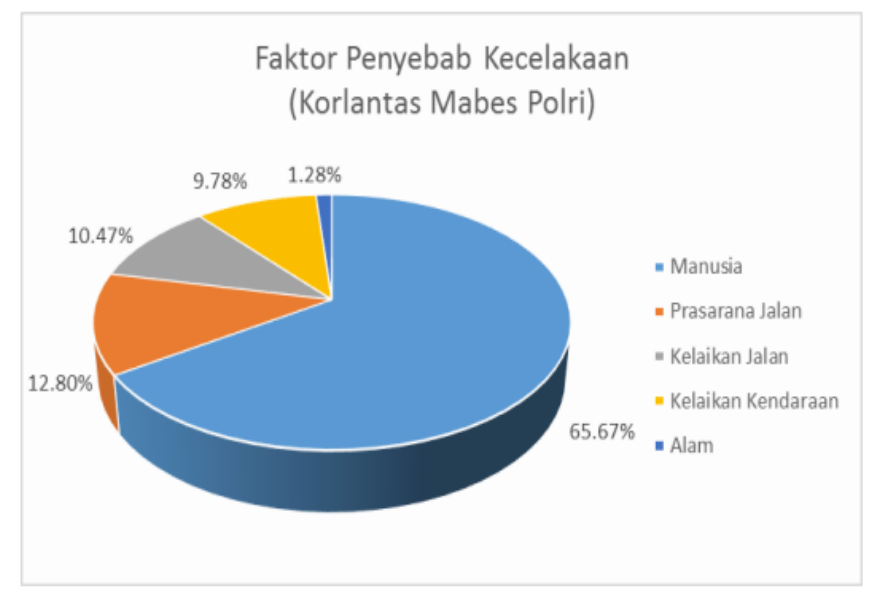

Kasus kecelakaan lalu lintas yang terjadi di Indonesia kebanyakan menimpa mereka yang berusia 15-25 tahun seperti yang dikutip dari http://www.mobil123.com yang dapat dilihat pada diagram batang berikut. 
Anik Widiastuti, Agus Sudarsono, Raras Gistha Rosardi

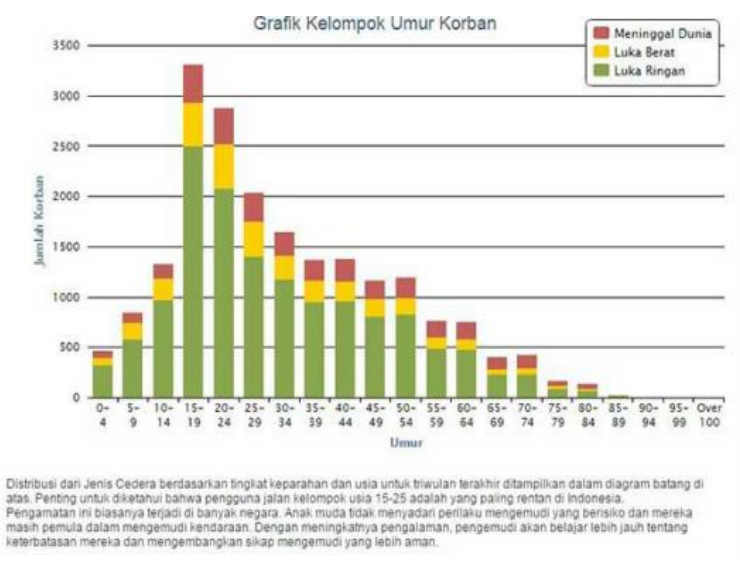

Diagram di atas menggambarkan bahwa usia 15 sampai dengan 25 tahun merupakan usia paling rentan, karena mereka yang termasuk dalam usia tersebut masih termasuk dalam kategori pemula dalam berkendara sehingga pengetahuan dan pengalaman yang dimiliki dalam berlalu lintas masih kurang, dan hal ini rentan menimbulkan terjadinya kecelakaan lalu lintas. Untuk itu perlu pengkondisian bagi anak yang akan memasuki usia tersebut dalam hal pendidikan bertransportasi termasuk bagi siswa yang masih duduk di bangku SMP sebagai upaya mengurangi terjadinya kecelakaan lalu lintas.

Edukasi transportasi sangat diperlukan untuk memberikan pengetahuan dan kecakapan menyangkut hal keselamatan bertransportasi. Dengan diajarkannya dasar keselamatan bertransportasi di sekolah-sekolah, anak-anak dipersiapkan untuk membangun pengetahuan tentang etika bertransportasi, dan sikap positif yang akan mendatangkan manfaat saat anak-anak itu menjadi dewasa di masa yang akan datang. Lebih mudah mengajarkan kebiasaan baik dari pada menyingkirkan kebiasaan buruk nantinya. Apa yang boleh dan tidak boleh dilakukan di 
jalan raya, bagaimana menghormati sesama pemakai jalan, pengenalan rambu-rambu lalu lintas adalah materi-materi dasar bertransportasi yang cocok diberikan kepada siswa SMP yang dapat dikemas dalam suatu kegiatan yang menarik sehingga lebih mudah untuk tertanam dalam pemahamannya dan mampu memberi nilai tambah bagi siswa itu sendiri.

Edukasi transportasi sebagai upaya pendidikan karakter siswa SMP yang disusun dengan cara yang menarik dan menyenangkan dilakukan untuk memudahkan mereka memahami dan menerapkan dalam kehidupan sehari-hari mengenai etika bertransportasi. Salah satu kegiatan yang menarik dan melibatkan siswa secara langsung salah satunya adalah melalui kegiatan simulasi. Di mana dengan simulasi secara langsung baik sebagai objek maupun subjek, siswa dapat lebih mudah memahami dan mengetahui apa yang salah dan apa yang seharusnya dilakukan ketika sebagai pemakai jalan dan pengendara. Seperti yang kita ketahui bahwa siswa SMP yang menginjak usia remaja awal perlu ditanamkan pendidikan karakter agar lebih berhati-hati saat bertransportasi sehingga tingkat emosional yang masih labil di usia remaja awal dapat dikendalikan agar dapat bertransportasi dengan aman.

Edukasi transportasi dapat dilakukan melalui jalur pendidikan sebagai upaya mendidik karakter siswa SMP. Salah satu SMP yang menjadi khalayak sasaran adalah SMP Insan Cendekia Turi. SMP Insan Cendekia Turi merupakan sekolah yang terletak di dekat jalan raya dengan lingkungan yang ramai kendaraan. Siswa yang bersekolah di SMP Insan Cendekia Turi banyak yang jarak rumahnya cukup jauh sehingga untuk mempermudah akses ke 
Anik Widiastuti, Agus Sudarsono, Raras Gistha Rosardi

sekolah orang tua dan pihak sekolah mengijinkan siswanya membawa motor. Padahal seharusnya siswa SMP belum boleh berkendara karena belum memenuhi batas usia minimal yang diperbolehkan sesuai aturan perundangan. Tentunya hal ini dapat membahayakan keselamatan baik bagi siswa itu sendiri maupun bagi pengendara lain, karena sebagai pengendara tidak cukup hanya dapat mengemudikan kendaraan bermotor saja tetapi dipengaruhi juga oleh faktor emosional. Pengendara dituntut memiliki emosi yang cukup stabil sehingga perilaku berkendara dapat lebih terkontrol. Siswa SMP berusia sekitar 12 sampai dengan 15 tahun. Pada usia ini tingkat emosi masih cukup labil dan dapat membahayakan diri sendiri maupun orang lain.

Oleh karena itu, dirasa cukup urgen untuk melakukan penelitian mengenai pemahaman edukasi transportasi sebagai upaya pendidikan karakter siswa di SMP Insan Cendekia Turi. Dengan edukasi transportasi ini diharapkan mampu memberikan pemahaman tentang etika bertransportasi dengan baik dan juga memberikan bekal keterampilan pada siswa dalam mengurangi resiko berkendara.

\section{Edukasi Transportasi}

Edukasi adalah penambahan pengetahuan dan kemampuan seseorang melalui teknik praktik belajar atau instruksi, dengan tujuan untuk mengingat faktaatau kondisi nyata, dengan cara memberi dorongan terhadap pengarahan diri (selfdirection), aktif memberikan informasi-informasi atau ide baru (Craven dan Hirnle, 1996 dalam Suliha, 2002). Pendapat lain dikemukakan Setiawati, 2008, edukasi merupakan serangkaian upaya yang 
ditujukan untuk mempengaruhi orang lain, mulai dari individu, kelompok, keluarga dan masyarakat agar terlaksananya perilaku hidup sehat.

Transportasi adalah pemindahan manusia atau barang dari satu tempat ketempat lainnya dalam waktu tertentu dengan menggunakan sebuah kendaraanyang digerakkan oleh manusia, hewan, maupun mesin. Definisi transportasi menurut beberapa ahli adalah sebagai berikut:

1. Menurut Morlok (1978), transportasi didefinisikan sebagai kegiatan memindahkan atau mengangkut sesuatu dari suatu tempat ke tempat lain.

2. Menurut Bowersox (1981), transportasi adalah perpindahan barang atau penumpang dari suatu tempat ke tempat lain, dimana produk dipindahkan ke tempat tujuan dibutuhkan. Dan secara umum transportasi adalah suatu kegiatan memindahkan sesuatu (barang dan/atau barang) dari suatu tempat ke tempat lain, baik dengan atau tanpa sarana.

3. Menurut Steenbrink (1974), transportasi adalah perpindahan orang atau barang dengan menggunakan alat atau kendaraan dari dan ke tempat-tempat yang terpisah secara geografis.

4. Menurut Papacostas (1987), transportasi didefinisikan sebagai suatu sistem yang terdiri dari fasilitas tertentu beserta arus dan sistem kontrol yang memungkinkan orang atau barang dapat berpindah dari suatu tempat ke tempat lain secara efisien dalam setiap waktu untuk mendukung aktivitas manusia. (Simanjuntak, 2011, http://repository.usu.ac.id/pdf). 
Anik Widiastuti, Agus Sudarsono, Raras Gistha Rosardi

Dari pengertian di atas dapat disimpulkan bahwa edukasi transportasi adalah proses belajar dari tidak tahu menjadi tahu mengenai tata aturan bertransportasi.

\section{Pendidikan Karakter}

Menurut Wynne dalam Darmiyati Zuchdi (2009: 10), istilah karakter diambil dari bahasa Yunani yang berarti "to mark" (menandai). Istilah ini lebih difokuskan pada bagaimana upaya pengaplikasikan nilai kebaikan dalam bentuk tindakan atau tingkah laku. Lebih lanjut, Wynne mengatakan ada dua pengertian tentang karakter, yakni pertama, ia menunjukkan bagaimana seseorang bertingkah laku dan kedua, istilah karakter erat kaitannya dengan personality.

Samsuri (2010: 2) memberikan terminologi "karakter" itu sendiri sedikitnya memuat dua hal values (nilai-nilai) dan kepribadian. Karakter merupakan cerminan dari nilai apa yang melekat dalam sebuah entitas. Karakter yang baik pada gilirannya adalah sebuah penampakkan dari nilai yang baik pula, yang dimiliki oleh orang atau sesuatu, di luar persoalan apakah "baik" sebagai sesuatu yang "asli" apakah sekadar kamuflase. Dari hal ini, maka kajian pendidikan karakter akan bersentuhan dengan wilayah filsafat moral atau etika yang bersifat universal, seperti kejujuran.

Pendidikan karakter menurut Febristina Nuraini adalah suatu sistem penanaman nilai-nilai karakter kepada warga sekolah yang meliputi komponen pengetahuan, kesadaran atau kemauan dan tindakan untuk melaksanakan nilai-nilai tersebut baik terhadap 
Tuhan YME, diri sendiri, sesama, lingkungan maupun kebangsaan sehingga menjadi manusia insan kamil (2012: 86).

Bertolak dari pendapat tersebut dapat disimpulkan bahwa pendidikan karakter tidak hanya berhubungan dengan orang lain, tetapi juga berkaitan dengan perilaku kita terhadap Tuhan YME, diri sendiri, lingkungan dan bangsa. Pendapat lain menyatakan bahwa pendidikan karakter sebagai pendidikan nilai menjadikan "upaya eksplisit mengajarkan nilai-nilai, untuk membantu siswa mengembangkan disposisi-disposisi guna bertindak dengan caracara yang pasti" (Curriculum Corporation, 2003: 33).

Persoalan baik dan buruk, kebajikan-kebajikan, dan keutamaan-keutamaan menjadi aspek penting dalam pendidikan karakter semacam ini. Karakter merupakan wujud kepribadian seorang individu yang diaktualisasikan dalam perilaku dengan ukuran norma dan nilai yang berlaku di masyarakat. Untuk menyatakan bahwa seorang individu memiliki karakter yang baik apabila mampu bertindak sesuai norama dan nilai yang berlaku dalam kehidupan sehari-harinya. Karakter dapat diperoleh melalui suatu cara yang disebut dengan pembiasaan. Pembiasaan dapat mendidik seseorang untuk berperilaku dengan terpola, sehingga hal ini dapat dilakukan melalui suatu proses pendidikan.

Menurut Timothy Wibowo (2011: 2), pencanangan pendidikan karakter tentunya dimaksudkan untuk menjadi salah satu jawaban terhadap beragam persoalan bangsa yang saat ini banyak dilihat, didengar dan dirasakan, yang mana banyak persoalan muncul yang di indentifikasi bersumber dari gagalnya pendidikan dalam menyuntikkan nilai-nilai moral terhadap peserta didiknya. 
Anik Widiastuti, Agus Sudarsono, Raras Gistha Rosardi

\section{Metode Penelitian}

Kegiatan penelitian ini menggunakan sample siswa SMP Insan Cendekia Turi, sebanyak 60 siswa yaitu kelas VIIIA dan VIIIB diharapkan dari siswa yang telah mengikuti pelatihan ini dapat menyebarluaskan kepada siswa lain di kelasnya serta kepada keluarga masing-masing sebagai wujud penyebarluasan edukasi transportasi dalam rangka meminimalisir terjadinya kecelakaan lalu lintas.

Metode kegiatan yang diawali dengan sosialisasi melalui ceramah tentang edukasi transportasi yang meliputi pemahaman konsep transportasi, tata tertib bertransportasi yang meliputi syarat-syarat berkendara dan pengenalan rambu-rambu lalu lintas. Kegiatan dilanjutkan dengan simulasi transportasi mengenai perilalu berkendara yang diperagakan oleh seluruh siswa.

\section{Hasil Penelitian dan Pembahasan}

Kegiatan penelitian terbagi dalam tiga sesi. Materi sesi pertama kegiatan pemberian materi dilaksanakan melalui ceramah mengenai pendidikan karakter dalam bertransportasi dengan cakupan mengenai berbagai permasalahan pelanggaran lalu lintas dan upaya pencegahannya melalui pendidikan karakter yang disampaikan oleh tim dosen Jurusan Pendidikan IPS, FIS, UNY.

Materi sesi kedua dilanjutkan dengan penyampaian materi mengenai tata tertib dan rambu-rambu lalu lintas yang disampaikan oleh tim dari Polres Sleman yang berjumlah 5 orang. Penyampaian materi menggunakan metode ceramah dan demonstrasi mengenai tata tertib berlalu lintas termasuk cara menggunakan helm yang tepat, etika berkendara, menyeberang jalan, memprioritaskan 
kendaraan yang akan lewat dll. Sesi ketiga dilanjutkan dengan simulasi perilaku bertransportasi yang mencakup etika dan tata cara berlalu lintas yang baik yang akan disimulasikan secara berkelompok. Tujuan dari kegiatan simulasi adalah setelah mengikuti materi pada sesi pertama dan kedua, siswa memahami peraturan dalam berlalu lintas, sehingga diharapkan mampu melaksanakan simulasi hal-hal yang seharusnya dilakukan saat dihadapkan pada suatu situasi. Simulasi dimainkan oleh kelompok yang mendapat giliran, sedangkan siswa lain diminta menganalisis kesalahan yang dilakukan dan mengidentifikasi akibat yang harus ditanggung pelanggar peraturan lalu lintas yang disimulasikan serta mengidentifikasi hal-hal yang tepat dan seharusnya dilakukan. Untuk kegiatan simulasi siswa dibagi dalam 5 kelompok, kemudian setiap kelompok mengambil undian untuk memerankan suatu tema. Tema-tema yang dipilih untuk disimulasikan adalah tema yang menggambarkan pelanggaran yang paling sering dilakukan oleh pengendara seperti berikut ini:

a. Tidak membawa SIM dan sanksinya

b. Membonceng tiga orang dan dampaknya

c. Mengendarai motor di trotoar untuk menghindari macet

d. Menerobos lampu merah dan proses sidang di pengadilan

e. Mengendarai kendaraan bermotor melawan arus di jalan satu arah

Kegiatan simulasi berlangsung lancar dan mampu digunakan sebagai salah satu tolok ukur untuk mengetahui sejauh mana pemahaman siswa terhadap materi yang telah diperoleh dari sesi pertama dan kedua. 
Anik Widiastuti, Agus Sudarsono, Raras Gistha Rosardi

Hasil tes dan angket dihitung dengan rumus menurut Sutrisno Hadi (1991: 353) yang dapat dikategorikan sebagai berikut:

1. $>(\mathrm{M}+1 \mathrm{SDi}) \quad=$ tinggi $/$ baik

2. $(\mathrm{M}-1 \mathrm{SDi}) \mathrm{s} / \mathrm{d}(\mathrm{M}+1 \mathrm{SDi})=$ sedang/cukup baik

3. $<(\mathrm{M}-1 \mathrm{SDi})=$ rendah/tidak baik

Adapun caranya yaitu dengan membandingkan antara nilai ratarata observasi dengan norma yang telah ditetapkan. Langkah penetapan norma tersebut adalah:

1. Menentukan skor terendah (SR) dan skor tertinggi (ST)

2. Menghitung rata-rata (mean) ideal yaitu $1 / 2(\mathrm{ST}+\mathrm{SR})$

3. Menghitung standar deviasi ideal $1 / 6(\mathrm{ST}-\mathrm{SR})$

Hasil evaluasi yang pertama adalah untuk mengukur pemahaman siswa terhadap materi edukasi transportasi. Identifikasi kecenderungan tinggi rendahnya pemahaman siswa terhadap edukasi transportasi yang dilaksanakan, ditetapkan berdasar kriteria ideal. Dari hasil tes diperoleh skor tertinggi (ST) 88 dan skor terendah (SR) 52. Untuk menentukan Mean ideal (Mi) dan Standar Deviasi ideal (SDi) dihitung acuan kriteria sebagai berikut:

$$
\begin{array}{rlrl}
\mathrm{Mi}=1 / 2(\mathrm{ST}+\mathrm{SR}) & \mathrm{SDi} & =1 / 6(\mathrm{ST}-\mathrm{SR}) \\
=1 / 2(88+52) & & =1 / 6(88-52) \\
=1 / 2(140) & & =1 / 6(36) \\
=70 & & \\
& & \mathrm{M}-1 \mathrm{SDi} & =70-1(6) \\
\mathrm{M}+1 \mathrm{SDi}=70+1(6) & =4 &
\end{array}
$$

Dengan harga Mi dan SDi tersebut dapat dikategorikan kecenderungan 
skor sebagai berikut:
a. $>(\mathrm{M}+1 \mathrm{SDi})$
$=>76$
$=$ tinggi
b. $(M-1 \mathrm{SDi}) \mathrm{s} / \mathrm{d}(\mathrm{M}+1 \mathrm{SDi})=64 \mathrm{~s} / \mathrm{d} 76$
= sedang
c. $<(\mathrm{M}-1 \mathrm{SDi})$
$=<64$
= rendah

Tabel 1. Hasil Perhitungan Skor Tes

\begin{tabular}{|l|l|l|}
\hline \multicolumn{1}{|c|}{ Kategori } & \multicolumn{1}{|c|}{ Rentang Skor } & \multicolumn{1}{c|}{ Jumlah } \\
\hline Tinggi & 76 ke atas & 27 \\
\hline Sedang & $64 \mathrm{~s} / \mathrm{d} 76$ & 23 \\
\hline Rendah & 64 bawah & 10 \\
\hline
\end{tabular}

Hal di atas menunjukkan bahwa penguasaan siswa terhadap materi edukasi transportasi dapat dikatakan baik karena didominasi oleh siswa yang memiliki skor hasil tes dalam kategori tinggi sebanyak 27 siswa dan yang memperoleh skor hasil tes dengan kategori rendah hanyak 10 siswa saja.

Hasil evaluasi yang kedua diperoleh melalui angket yang bertujuan untuk mengetahui kepuasan siswa terhadap pelaksanaan penelitian. Identifikasi kecenderungan tinggi rendahnya skor angket kepuasan siswa dengan kegiatan penelitian yang dilaksanakan ditetapkan berdasar kriteria ideal. Dari hasil tes diperoleh skor tertinggi (ST) 50 dan skor terendah (SR) 21. Untuk menentukan Mean ideal (Mi) dan Standar Deviasi ideal (SDi) dihitung acuan kriteria sebagai berikut:

$$
\begin{aligned}
& \mathrm{Mi}=1 / 2(\mathrm{ST}+\mathrm{SR}) \\
& \mathrm{SDi}=1 / 6(\mathrm{ST}-\mathrm{SR}) \\
& =1 / 2(50+21) \\
& =1 / 6(50-21) \\
& =1 / 2(71) \\
& =1 / 6(29) \\
& =35,5 \\
& =4,83
\end{aligned}
$$




$$
\begin{aligned}
\mathrm{M}+1 \mathrm{SDi}=35,5+1(4,83) & \mathrm{M}-1 \mathrm{SDi} & =35,5-1(4,83) \\
= & 40,33 & =30,67
\end{aligned}
$$

Dengan harga Mi dan SDi tersebut dapat dikategorikan kecenderungan skor hasil angket sebagai berikut:

$$
\begin{array}{ll}
>(\mathrm{M}+1 \mathrm{SDi})=>40,33 & =\text { tinggi } \\
(\mathrm{M}-1 \mathrm{SDi}) \mathrm{s} / \mathrm{d}(\mathrm{M}+1 \mathrm{SDi})=30,67 \mathrm{~s} / \mathrm{d} 40,33 & =\text { sedang } \\
<(\mathrm{M}-1 \mathrm{SDi})=<30,67 & =\text { rendah }
\end{array}
$$

Tabel 2. Hasil Perhitungan Skor Angket

\begin{tabular}{|l|l|l|}
\hline \multicolumn{1}{|c|}{ Kategori } & \multicolumn{1}{|c|}{ Rentang Skor } & \multicolumn{1}{c|}{ Jumlah } \\
\hline Tinggi & 40,33 ke atas & 38 \\
\hline Sedang & $30,67 \mathrm{~s} / \mathrm{d} 40,33$ & 17 \\
\hline Rendah & 30,67 bawah & 5 \\
\hline
\end{tabular}

Hal di atas menunjukkan bahwa kepuasan siswa terhadap kegiatan PPM dapat dikatakan baik karena didominasi oleh siswa yang memberi skor angket dalam kategori tinggi sebanyak 38 siswa dan yang memberi skor hasil angket dengan kategori rendah hanyak 5 siswa saja.

Pelaksanaan penelitian dimulai dengan diterimanya proposal penelitian berjudul "Pemahaman Edukasi transportasi sebagai upaya pendidikan karakter siswa di SMP Insan Cendekia Turi” oleh FIS, UNY. Tim merasa perlu melakukan kegiatan ini dikarenakan lokasi SMP Insan Cendekia Turi terletak di kawasan yang cukup ramai dan banyak siswanya yang ke sekolah membawa kendaraan bermotor. Sekolah tidak mampu melarang siswanya dikarenakan sulitnya kendaraan umum yang menjangkau sekolah dengan 
rumah siswa sehingga terpaksa memperbolehkan siswanya membawa kendaraan bermotor. Sekolah juga kurang mendapat perhatian dari instansi luar karena sekolah swasta sehingga demi meningkatkan kerjasama dengan pihak luar sekolah membutuhkan pelaksanaan PPM ini sebagai upaya peningkatan pemahaman materi tambahan di luar materi pelajaran sekolah.

Oleh karena itu kegiatan penelitian ini dilakukan melalui ceramah saja akan tetapi dimodifikasi dengan simulasi. Harapannya setelah siswa-siswi memiliki pemahaman mengenai tata tertib berlalu lintas yang benar, siswa-siswi tersebut memiliki keterampilan dalam mengaplikasikan peraturan tersebut dalam kehidupan seharihari saat berkendara. Usia SMP pada prinsipnya belum diperbolehkan mengendarai kendaraan bermotor, akan tetapi karena berbagai alasan sekolah terpaksa mengijinkan siswanya membawa kendaraan bermotor ke sekolah, sehingga bagi mereka terutama yang membawa kendaraan bermotor diharapkan memahami halhal yang seharusnya dilakukan dan tidak boleh dilakukan saat berkendar. Hal ini ditujukan agar terbentuk karakter disiplin dalam berlalu lintas pada siswa sasaran kegiatan penelitian.

Tim peneliti mendapat kemudahan mulai dari mengurus perizinan, dari pihak sekolah sangat membantu kelancaran perizinan karena berkepentingan dengan upaya meningkatkan pemahaman dan keterampilan siswa-siswinya dalam kaitannya dengan etika berlalu lintas. Pertemuan yang dilakukan dengan pihak sekolah yang diwakili kepala sekolah dan wakil kepala urusan kesiswaan disosialisasikan kepada siswa-siswi kelas kelas VII yang dijadikan target sasaran sebagai subjek penelitian serta kepada guru-guru. 
Anik Widiastuti, Agus Sudarsono, Raras Gistha Rosardi

Demikian juga pihak sekolah yang sangat membantu mulai dari persiapan, pensosialisasian, penyiapan tempat dan peralatannya. Selain itu pihak ketiga yang bekerjasama dalam kegiatan penelitian yang dalam hal ini adalah Polres Sleman khususnya bagian Dikyasa Lantas juga sangat kooperatif demi mendukung terlaksananya program. Hal ini dikarenakan bagian Dikyasa Lantas juga memiliki misi untuk mengedukasi masyarakat kaitannya dalam berlalu lintas agar mematuhi peraturan dan tata tertib sehingga dapat meminimalisir terjadinya kecelakaan lalu lintas. Dikyasa Lantas mengalami beberapa kesulitan dikarenakan program pendidikan lalu lintas tidak dapat masuk dalam kurikulum persekolahan selayaknya sekolah-sekolah di luar negeri padahal program pendidikan lalu lintas sangat penting untuk dilakukan sejak usia dini. Selama ini kegiatan pendidikan lalu lintas hanya dapat masuk di sekolah saat kegiatan MOS yang waktunya sangat singkat dan dirasa belum cukup untuk mengedukasi siswa dalam bertransportasi.

Pertemuan dengan pihak sekolah kemudian dilanjutkan dengan pelaksanaan penelitian yang dibagi dalam tiga sesi. Materi pertama berupa sosialisasi pendidikan karakter dalam bertransportasi yang meliputi syarat-syarat berkendara yang aman, jenis-jenis kesalahan yang sering dilakukan pengguna jalan, serta etika yang tepat dalam berkendara. Materi ini disampaikan melalui kegiatan ceramah. Sesi kedua berisi mengenai tata tertib dan rambu-rambu lalu lintas yang dilakukan melalui kegiatan ceramah dan demonstrasi. Sesi ketiga dilakukan simulasi perilaku dalam bertransportasi dimana siswa dibagi menjadi 5 kelompok, masing-masing kelompok beranggotakan 12 
siswa yang dibimbing oleh 1 anggota tim peneliti Jurusan Pendidikan IPS, FIS, UNY. Tingkat kehadiran mencapai 120 persen. Hal ini menunjukkan antusiasme sekolah dalam memfasilitasi kegiatan penelitian. Pada awalnya, tim peneliti menargetkan 50 siswa sebagai sasaran penelitian yang merupakan perwakilan kelas, akan tetapi karena sekolah merasa perlu untuk diberikan kepada seluruh siswa kelas VIII yang berjumlah 60 siswa.

Penelitian ini sangat dibutuhkan oleh sekolah karena dirasa urgen dan penting materi edukasi transportasi bagi siswa kelas VIII SMP Insan Cendekia dimana banyak siswa kelas VIII yang membawa kendaraan bermotor padahal secara usia belum diperbolehkan berkendara. Selain itu siswa SMP Insan Cendekia Turi juga memiliki pengetahuan yang sangat terbatas mengenai tata tertib berkendara. Melihat hasil penelitian dan respon dari sekolah, kegiatan penelitian dirasa cukup berhasil, walaupun masih terdapat kekurangan dalam pelaksanaannya karena keterbatasan saranaprasarana yang ada, keterbatasan waktu, keterbatasan anggaran dan juga keterbatasan tim peneliti sendiri dalam hal merancang simulasi yang efektif dan efisien.

\section{Simpulan}

Berdasarkan uraian dalam pembahasan maka dapat disampaikan bahwa kegiatan penelitian Pemahaman Edukasi Transportasi sebagai Upaya Pendidikan Karakter Siswa SMP Insan Cendekia Turi, menghasilkan simpulan sebagai berikut:

1. Pemahaman Edukasi transportasi yang telah dilaksanakan melalui seluruh rangkaian kegiatan penelitian bekerja sama dengan Polres Sleman unit Dikyasa Lantas dapat meningkatkan pemahaman 
Anik Widiastuti, Agus Sudarsono, Raras Gistha Rosardi

siswa mengenai syarat berkendara yang tepat, etika dalam berkendara, tata tertib berlalu lintas, serta arti rambu-rambu lalu lintas.

2. Penelitian yang dilakukan dapat memberikan wawasan bagi siswa bahwa seharusnya siswa SMP belum diperbolehkan mengendarai kendaraan bermotor, sehingga apabila siswa berkendara harus mentaati peraturan yang berlaku.

3. Simulasi perilaku bertransportasi yang dilaksanakan diharapkan dapat meningkatkan keterampilan siswa SMP Insan Cendekia Turi dalam berkendara sebagai upaya pendidikan karakter siswa.

\section{Saran}

Berdasarkan simpulan di atas dapat dirumuskan beberapa saran sebagai berikut:

1. Program penelitian ini diharapkan dapat dilanjutkan mengingat baru terlaksana bagi siswa kelas VIII SMP Insan Cendekia Turi, dan belum seluruh siswa mengikutinya.

2. Materi edukasi transportasi dapat ditambah dengan praktik agar siswa nantinya dapat berkendara dengan benar sesuai peraturan yang berlaku.

3. Pelaksanaan penelitian perlu diperpanjang waktunya dikarenakan proses simulasi membutuhkan waktu yang cukup banyak agar siswa benar-benar memahami hal-hal yang tepat dilakukan saat saat berkendara. 
JIPSINDO No. 1, Volume 4, Maret 2017

\section{Daftar Pustaka}

Darmiyati Zuchdi. (2009). Pendidikan karakter. Yogyakarta: UNY Press.

Febristina Nuraini. (2012). Stimulasi motivasi belajar sebagai upaya menumbuhkan karakter pada anak usia dini. Prosiding. Yogyakarta: Fakultas Ilmu Sosial Universitas Negeri Yogyakarta.

https://aplikasiergonomi.wordpress.com/2014/05/22/analisa-

kecelakaan lalu-lintas-di-indonesia-dengan-penggunakendaraan-bermotor-serta-penyebabnya/ Diakses pada hari selasa 23 Agustus 2016 pukul 10.23 WIB

https://edorusyanto.wordpress.com/2014/04/11/ironi-sebelumayam berkokok/ Diakses pada hari selasa 23 Agustus 2016 pukul 10.26

WIB

(http://palembang.tribunnews.com/2011/12/01/who-lalaipenyebab-utama-kecelakaan-di-indonesia). Diakses pada hari Senin, 28 Maret 2016 pukul 08.20 WIB

http:/ /www.beritasatu.tv/kutipan/kecelakaan-lalu-lintas/Diakses pada hari selasa 23 Agustus 2016 pukul 10.21 WIB

http://www.bin.go.id/awas/detil/197/4/21/03/2013/kecelakaanlalu-lintas-menjadi-pembunuh-terbesar-ketiga. Diakses pada hari Senin, 28 Maret 2016 pukul 08.10 WIB

Pandensolang. 2015.2 Diakses dari ejournal.uajy.ac.id/7732/3/TA213706.pdf pada hari Senin tanggal 28 Maret 2016 pukul 08.46 WIB.

Simanjuntak, 2011. Diakses dari http:// repository.usu.ac.id/bitstream/123456789/24137/3/Chapter \%20II.pdf. pada hari Senin tanggal 28 Maret 2016 pukul 08.40 WIB

Timothy Wibowo (2011). Mewujudkan Pendidikan Karakter yang Berkualitas. http://www.pendidikankarakter.com. Diunduh pada hari Kamis tanggal 18 Oktober 2012 pukul 14.53 WIB. 